\title{
Instrumenty kształtowania struktury obszarowej gospodarstw rolnych w Polsce ze szczególnym uwzględnieniem roli instrumentów finansowych
}

Grunty rolne stanowią podstawowy składnik majątkowy gospodarstw rolnych. Bez nich ani faktycznie, ani formalnie nie może istnieć gospodarstwo rolne. W zależności od profilu produkcji rolnej gospodarstwo powinno posiadać odpowiedni areał gruntów rolnych. Wielkość tego areału decyduje współcześnie w coraz większym stopniu o kondycji finansowej gospodarstw rolnych. Większe obszarowo gospodarstwa rolne lepiej sobie radzą w obecnych, trudnych sytuacjach kryzysowych.

W polityce rolnej naszego Państwa okresu powojennego jednym z ważnych celów było pełne zabezpieczenie potrzeb żywnościowych społeczeństwa, zarówno $\mathrm{w}$ aspekcie ilościowym, jak i w zakresie zapewnienia pełnego asortymentu produktów żywnościowych. W okresie do roku 1990 potrzeby te udawało się zaspokajać zaledwie w zakresie podstawowym. Pełnego, dostępnego dla wszystkich konsumentów asortymentu produktów żywnościowych nigdy nie udało się niestety osiągnąć.

Sytuacja zmieniła się po 1989 roku wraz z urynkowieniem gospodarki Państwa, w tym także gospodarki żywnościowej. Nowe realia gospodarcze wprawdzie bardzo szybko rozwiązały problemy żywnościowe kraju, przyniosły jednak nowe problemy. W warunkach rynkowych nadwyżek żywności, które ujawniły się w przeciągu zaledwie kilku lat po rozpoczęciu transformacji ustrojowej, problemem podstawowym staje się brak wystarczających dochodów w gospodarstwach rolnych. Ich brak nie pozwalał niejednokrotnie na utrzymanie produkcji w gospodarstwach rolnych na dotychczasowym poziomie, a tym bardziej na ich rozwój.

Praktyka rolnicza wypracowała wiele instrumentów prowadzących do poprawy dochodów w gospodarstwach rolnych. Wśród nich ważne miejsce przypada działaniom stymulującym pożądaną strukturę obszarową gospodarstw rolnych. Powszechnie uważa się, że większe obszarowo gospodarstwa dają lepszą gwarancję na uzy- 
Instrumenty kształtowania struktury obszarowej gospodarstw rolnych w Polsce...

skanie wyższych dochodów. Potwierdza to zresztą praktyka funkcjonowania tych gospodarstw.

Zanim jednak przejdziemy do szerszych rozważań w zakresie wdrażanych zarówno w przeszłości, jak i obecnie działań ukierunkowanych na poprawę struktury obszarowej gospodarstw rolnych, uzasadnionym będzie uprzednie odpowiedzi na pytanie, dlaczego struktura obszarowa gospodarstw rolnych w Polsce jest niezadowalająca i dlaczego wymaga poprawy.

Zważywszy na prawniczy charakter niniejszej pracy, wydaje się, że na użytek prowadzonych w niej rozważań najbardziej przydatnymi będą zaprezentowane w tym zakresie w literaturze ekonomicznej rozważania autorstwa Waldemara Michny $^{2}$. Zwraca on mianowicie uwagę na to, że potrzeb żywnościowych (około 40-milionowego społeczeństwa) oraz nieżywnościowych (chodzi przede wszystkim o surowce rolne do produkcji odnawialnych źródeł energii na potrzeby transportu i energetyki) łącznie wziętych nie będą w stanie zabezpieczyć funkcjonujące w Polsce gospodarstwa rolne. Dzieje się tak, ponieważ plony w gospodarstwach rolnych nie zwiększają się, a przyczyna tego stanu rzeczy tkwi w strukturze ekonomicznej gospodarstw rolnych. Autor tych wywodów, mając na uwadze urzędowe badania statystyczne, ${ }^{3}$ twierdzi, że na ogólną liczbę ponad 1,7 mln gospodarstw rolnych 215 tys. sprzedało roczną produkcję towarową o wartości większej niż 30 tys. zł. (średnio 147 tys. zł). Ta liczba gospodarstw rolnych po pokryciu kosztów produkcji w wysokości ok. 45\% wartości produkcji towarowej jest w stanie odtworzyć potencjał produkcyjny i zwiększyć nakłady na bieżącą produkcję. Jeśli do tej kwoty dodać wartość dopłaty bezpośredniej (przeciętna wysokość dopłat bezpośrednich na jedno gospodarstwo wynosi ok. 20 tys. zł), to przyjąć należy, że ta grupa gospodarstw może być zaliczona do grupy gospodarstw rozwojowych. Dodać przy tym należy, że przeciętna powierzchnia tych gospodarstw wynosi niespełna 40 ha użytków rolnych, a łącznie uprawia się w nich ok. $8 \mathrm{mln}$ ha użytków rolnych spośród 15,9 mln ha całości użytków rolnych w Polsce.

Spośród liczby 1,41 mln gospodarstw realizujących produkcję rolną blisko 1,2 mln gospodarstw nie ma możliwości zwiększenia nakładów na wzrost plonów o wzrost produkcji. Ta grupa gospodarstw rolnych użytkuje drugą połowę użytków rolnych.

Zdaniem autora przywoływanej tutaj publikacji zmiana struktury agrarnej powinna zmierzać do tego, aby przynajmniej l’ użytków rolnych znalazło się w grupie gospodarstw rozwojowych. Uważa on, że nową falę koncentracji należy oprzeć

Zawarte w opracowanej w Instytucie Ekonomiki Rolnictwa i Gospodarki Żywnościowej ekspertyzie tegoż autora na temat „Sterowane i samoistne przemiany struktury agrarnej w różnych regionach kraju, Seria: komunikaty, raporty, ekspertyzy, nr 529, Warszawa 2007. 
na nowych grupach gospodarstw, które posiadają już 10-15 ha, a poprzez włączenie dodatkowo 5-10 ha ziemi sąsiadów staną się gospodarstwami rozwojowymi. W województwach Polski południowo-wschodniej kryteria te należy dostosować do większego rozdrobnienia struktury agrarnej.

Ten kierunek przekształceń w strukturze agrarnej naszego kraju zdaje się stymulować obecne rozporządzenie Ministra Rolnictwa i Rozwoju Wsi z dnia 19 czerwca 2007 roku w sprawie szczegółowych warunków i trybu przyznawania pomocy finansowej w ramach działania „Renty strukturalne” objętego Programem Rozwoju Obszarów Wiejskich na lata 2007-20134, zwłaszcza w swym kształcie po jego ostatniej nowelizacji z dnia 16 lipca 2010 roku $^{5}$. Generalnie przyporządkowuje ono rentom strukturalnym - jako główną funkcję - poprawę struktury agrarnej gospodarstw rolnych. Będzie o tym szerzej mowa w dalszej części niniejszej pracy.

$* * * *$

Jak to wcześniej wykazano, stymulowanie pożądanej struktury agrarnej gospodarstw rolnych w większości europejskich państw nie pozostawiono wyłącznie mechanizmom rynkowym, lecz w proces ten angażowały się również instytucje państwowe, stosując najprzeróżniejsze formy tej stymulacji. Podobnie, również w Polsce w całym okresie powojennym w proces ten angażowały się w równej mierze władze polityczne oraz państwowe.

W latach 1949-1956 podjęto w Polsce zdecydowane działania zmierzające do przeprowadzenia systemowych zmian struktury agrarnej gospodarstw rolnych poprzez tworzenie rolniczych spółdzielni produkcyjnych. Działania te nie powiodły się z uwagi na powszechny opór rolników, którzy niechętnie wstępowali do tych spółdzielni, nawet w warunkach stosowanej wobec nich presji ekonomicznej w postaci zwiększonych kontyngentów obowiązkowych dostaw płodów rolnych oraz mocno progresywnych stawek podatkowych, których realizacja obwarowana była nawet sankcjami karnymi.

Po 1956 roku ustawodawstwo rolne nastawione było na zapobieganie rozdrabnianiu indywidualnych gospodarstw rolnych, najpierw poprzez zakaz ich podziału, następnie poprzez administracyjną kontrolę norm obszarowych w cywilnoprawnym obrocie nieruchomościami ${ }^{6}$.

Lata siedemdziesiąte ubiegłego wieku przyniosły w Polsce nowe tendencje w zakresie zagospodarowania ziemi rolniczej. Rozwijający się wówczas przemysł

Dz.U. Nr 109, poz. 750 ze zm.

Dz.U. Nr 131, poz. 886.

Por. zwłaszcza: ustawę z dnia 15 lipca 1957 r. o obrocie nieruchomościami rolnymi (Dz.U. Nr 39, poz 172 ze zm.); ustawę z dnia 29 czerwca 1963 r. o ograniczeniu podziału gospodarstw rolnych (Dz.U. Nr 28, poz. 168); ustawę z dnia 23 kwietnia 1964 r. - Kodeks cywilny. 
powodował zjawisko powszechnego zatrudniania się młodych rolników poza rolnictwem, w efekcie wyludnianie się wielu gospodarstw rolnych. Problem ten Państwo próbowało rozwiązywać początkowo poprzez przyznawanie specjalnych rent dla rolników w zamian za przekazane Państwu gospodarstwo rolne ${ }^{7}$, a następnie poczynając od 1978 roku - emerytur i rent rolniczych ${ }^{8}$. Świadczenia te przyznawane na podstawie ustawy z dnia 27 października 1977 roku miały wypełniać kilka ważnych społeczno-gospodarczych celów. Przyznanie rolnikowi świadczenia emerytalnego czy rentowego miało przede wszystkim stanowić dla niego zabezpieczenie materialne po przekazaniu gospodarstwa rolnego swemu następcy bądź Państwu. Stworzenie tą ustawą możliwości przekazywania gospodarstw rolnych następcom miało z kolei na celu powstrzymanie mającego wówczas miejsce swego rodzaju ,exodusu” młodzieży z terenów wiejskich do miast, gdzie istniała wówczas możliwość szybszego i stosunkowo łatwego ,urządzenia się”. Wreszcie emerytury bądź renty w zamian za przekazane Państwu gospodarstwo rolne, miały w zamyśle ustawodawcy stanowić sposób na pozyskiwanie ziemi rolniczej dla uspołecznionego sektora rolnego (państwowych gospodarstw rolnych, rolniczych spółdzielni produkcyjnych oraz zespołowych gospodarstw rolnych spółdzielni kółek rolniczych).

Możliwość uzyskania emerytury bądź renty rolniczej w zamian za przekazane Państwu gospodarstwo rolne została ograniczona pod rządami ustawy z dnia 14 grudnia 1982 roku o ubezpieczeniu społecznym rolników i członków ich rodzin9. Rolnik mógł wówczas przekazać gospodarstwo rolne Państwu jedynie w przypadku gdy nikt spośród jego następców nie mógł bądź nie chciał przejąć gospodarstwa rolnego w trybie przepisów tej ustawy. To rozwiązanie, podobnie jak to miało miejsce w przypadku wielu innych jeszcze ustaw rolnych z pierwszych lat 80-tych ubiegłego stulecia, stanowiło wyraz wzmocnienia jej przepisami ochrony prawnej indywidualnej własności rolniczej. Dodać przy tym należy, że żadna z ustaw o ubezpieczeniu społecznym rolników, w tym także obowiązująca obecnie, nie zawierała i nie zawiera rozwiązań, które stymulowałyby poprawę struktury obszarowej gospodarstw rolnych. Można zatem przyjąć pogląd, że efektem stosowania rozwiązań normatywnych dotyczących przekazywania gospodarstw rolnych następcom, w trybie przepisów zawartych w kolejno następujących po sobie ustawach o ubezpieczeniu społecznym rolników, było i nadal pozostaje utrzymanie dotychczasowego status quo w zakresie struktury obszarowej indywidualnych gospodarstw rolnych.

W latach siedemdziesiątych ubiegłego stulecia ze strony Państwa podejmowane były inne jeszcze działania, które pośrednio bądź bezpośrednio oddziaływały na

$7 \quad$ W latach 70-tych podstawę prawną do przyznania takiej renty stanowiła przykładowo m.in. ustawa z dnia 29 maja 1974 roku o przekazywaniu gospodarstw rolnych na własność Państwa za rentę i spłaty pieniężne (Dz.U. Nr 21, poz. 118).

$8 \quad$ Na podstawie ustawy z dnia 27 października 1977 roku o zaopatrzeniu emerytalnym oraz innych świadczeniach dla rolników i ich rodzin (Dz.U. Nr 32, poz. 140).

9 Dz.U. z 1989 r. Nr 24, poz. 139 i Nr 35, poz. 190 oraz z 1990 r. Nr 14, poz. 90 i Nr 34, poz. 198. 
poprawę struktury obszarowej indywidualnych gospodarstw rolnych. Chodzi tutaj o stosowane w tym czasie różnego rodzaju formy finansowego i materiałowego wspierania rolnictwa indywidualnego. Zaliczyć do nich należy w szczególności: umarzalne kredyty bankowe, przydział deficytowych środków do produkcji rolnej, czy pierwszeństwo w zakupie gruntów Państwowego Funduszu Ziemi. Pomoc ta zaowocowała powstaniem i umocnieniem wielu tysięcy towarowych, a także specjalistycznych gospodarstw rolnych. To w tych właśnie gospodarstwach rolnych wzrosło zainteresowanie zakupem ziemi, zwłaszcza tam, gdzie profil produkcji rolnej wymuszał potrzebę posiadania większego areału gruntów rolnych (np. w gospodarstwach hodowlanych).

Dla pełnego obrazu dodać należy, że w latach siedemdziesiątych ubiegłego stulecia z dużego wsparcia ze strony Państwa korzystały również uspołecznione gospodarstwa rolne. Rozwój obszarowy tych gospodarstw uzależniony był w głównej mierze od tempa pozyskiwania ziemi $z$ indywidualnego sektora rolnego. Jak to już wyżej wykazano, tempo to zostało wyhamowane przepisami ustawodawstwa rolnego lat osiemdziesiątych. Zasadniczy kierunek tego ustawodawstwa zmierzał bowiem generalnie do wzmocnienia ochrony prawnej indywidualnej własności rolniczej. Szczególnym wyrazem tego wzmocnienia było wyeliminowanie z ustawodawstwa rolnego ,sankcji własnościowych", stosowanych wobec rolnictwa indywidualnego, które w zamyśle ustawodawcy miały przeciwdziałać ekstensywnemu użytkowaniu gruntów rolnych. Ustawy te dotyczyły przykładowo gospodarstw wykazujących niski poziom produkcji rolnej, ekonomicznie zadłużonych, opuszczonych. W praktyce ich stosowania, zwłaszcza w latach siedemdziesiątych, stanowiły one podstawę prawną, często nieuzasadnionego, sprzecznego z treścią zawartych w nich przepisów, przejmowania przez Skarb Państwa indywidualnych gospodarstw rolnych. W ustawodawstwie rolnym tego okresu pozostawiona została jedynie jedna sankcja typu własnościowego, stosowana w przypadku opuszczonych gospodarstw rolnych ${ }^{10}$.

Lata osiemdziesiąte ubiegłego stulecia, na skutek kryzysu ekonomicznego, przyniosły osłabienie polityki wspierania rolnictwa różnymi formami pomocy, zwłaszcza finansowej, stosowanymi dość szeroko w latach siedemdziesiątych. W obrocie nieruchomościami rolnymi zniesione zostały dotychczasowe ograniczenia obszarowe. Obrót tymi nieruchomościami był generalnie dopuszczalny, o ile prowadził do utworzenia gospodarstwa rolnego zdolnego do towarowej produkcji rolnej. Mogło to $\mathrm{z}$ jednej strony prowadzić $\mathrm{w}$ wielu przypadkach do nieuzasadnionego ekonomicznie podziału gospodarstw rolnych. $\mathrm{Z}$ drugiej natomiast strony, zwłaszcza zniesienie górnej normy obszarowej indywidualnego gospodarstwa rolnego sprzyjało koncen- 
tracji ziemi w większych gospodarstwach rolnych o profilu produkcji wymagającym większego areału gruntów rolnych. W praktyce te zmiany w ustawodawstwie rolnym nie spowodowały istotnych zmian w strukturze obszarowej indywidualnych gospodarstw rolnych.

Zapoczątkowany po 1989 roku okres transformacji ustrojowej przyniósł w pierwszych już latach dwie zasadnicze zmiany, które miały istotny wpływ na kształtowanie struktury obszarowej gospodarstw rolnych. Zmiana pierwsza to ukierunkowanie gospodarki rolnej na jej prywatyzację (czego konsekwencją była likwidacja państwowych gospodarstw rolnych). Druga z kolei to próba poddania gospodarki rolnej w całości prawom rynku (konsekwencją tego było wycofanie się z dotacji dla rolnictwa). W następnych dopiero latach polityka rolna Polski zaczęła upodobniać się do Wspólnej Polityki Rolnej, wdrażając już systemowo różne formy pomocy finansowej skierowanej na modernizację i zmiany strukturalne w rolnictwie oraz w branży przetwórczej ${ }^{11}$.

W dniu 19 stycznia 1994 roku weszła w życie ustawa z dnia 29 grudnia 1993 roku o utworzeniu Agencji Restrukturyzacji i Modernizacji Rolnictwa ${ }^{12}$. Wśród zadań tej Agencji ważne miejsce wyznaczono działaniom mających na celu poprawę struktury agrarnej gospodarstw rolnych. Cel ten został wyraźnie wyartykułowany w przepisie $\S 2$ rozporządzenia Rady Ministrów z dnia 22 marca 1994 roku w sprawie szczegółowych kierunków działań Agencji Restrukturyzacji i Modernizacji Rolnictwa oraz sposobów ich realizacji ${ }^{13}$. Kolejne wydawane w tej sprawie rozporządzenia Rady Ministrów zachowały brzmienie tego przepisu, z istotną jego zmianą dokonaną w 2003 roku po wejściu w życie ustawy z dnia 11 kwietnia 2003 roku o kształtowaniu ustroju rolnego ${ }^{14}$. Przepis $§ 2$ obowiązującego wówczas w tej sprawie rozporządzenia Rady Ministrów z dnia 30 stycznia 1996 roku ${ }^{15}$ przedmiotową pomoc ukierunkował na działania w postaci kupna nieruchomości rolnych i urządzania gospodarstw rolnych, w tym zwłaszcza w celu tworzenia lub powiększania gospodarstw rodzinnych w rozumieniu przepisów o kształtowaniu ustroju rolnego. Dodać tutaj należy, że pomoc ta była równolegle kierowana na urządzanie nieruchomości rolnych dzierżawionych w okresach wieloletnich.

Pod rządami nowej ustawy z dnia 9 maja 2008 roku o Agencji Restrukturyzacji i Modernizacji Rolnictwa analizowany tutaj kierunek wsparcia finansowego zo-

Ten kierunek polityki rolnej pozostawał w związku ze złożonym w dniu 8 kwietnia 1994 roku formalnym wnioskiem o członkostwo Polski w Unii Europejskiej. Zauważyć tutaj należy, że uzyskanie tego członkostwa warunkowane było wymogiem dostosowania rolnictwa i branży przetwórczej do standardów unijnych. 
stał utrzymany, z tym, że w $\S 3$ ust. 2 pkt 8 rozporządzenia wykonawczego do tej ustawy z dnia 22 stycznia 2009 roku w sprawie realizacji niektórych zadań Agencji Restrukturyzacji i Modernizacji Rolnictwa ${ }^{16}$ przedmiotowe wsparcie ukierunkowane zostało tym przepisem generalnie na poprawę struktury agrarnej. Tak jak w poprzednich przepisach, nie precyzuje się już wprost tego wsparcia w obszarze tworzenia i powiększania gospodarstw rodzinnych. Niemniej jednak w myśl § 10 ust. 4 pkt 2 lit. a) tego rozporządzenia wsparcia nie stosuje się do części nabywanych użytków rolnych, która spowoduje powiększenie powierzchni gospodarstwa rolnego lub gospodarstw rolnych będących w posiadaniu tego samego producenta od ponad 300 ha użytków rolnych. Oznacza to, że poprzez wskazanie powyższego kryterium obszarowego, nawiązującego do górnej granicy obszarowej gospodarstwa rodzinnego, prawodawca tylko takie objął swą pomocą.

W kolejności wypada wskazać na inną formę pomocy finansowej zapoczątkowanej w pierwszych latach 90-tych ubiegłego stulecia. Jest nią nieprzerwanie udzielana do dzisiaj przez Agencję Restrukturyzacji i Modernizacji Rolnictwa dopłata do oprocentowania kredytu bankowego udzielanego przez bank, m.in. na zakup nieruchomości rolnych. Nie wdając się w szczegóły co do bliższego przybliżenia istoty tego instrumentu pomocowego, dopłata do oprocentowania kredytów na zakup ziemi objęta została większą preferencją. W tym przypadku oprocentowanie płacone bankowi przez kredytobiorcę może wynosić nawet $2 \%$ zastosowanego w danym przypadku oprocentowania kredytu ${ }^{17}$. Taką samą preferencję w oprocentowaniu stosuje się w przypadku kredytów na zakup użytków rolnych w celu powiększenia lub utworzenia nowego gospodarstwa rolnego o powierzchni nie mniejszej od ogłoszonej na podstawie przepisów o płatnościach w ramach systemów wsparcia bezpośredniego średniej powierzchni użytków rolnych w danym województwie, a także kredytów na utworzenie gospodarstwa rodzinnego w rozumieniu przepisów o kształtowaniu ustroju rolnego lub powiększenie takiego gospodarstwa.

Dla potrzeb prowadzonej tutaj analizy pożytecznym będzie syntetyczne przybliżenie kryteriów dostępu do kredytów na zakup gruntów rolnych objętych dopłatami Agencji Restrukturyzacji i Modernizacji Rolnictwa. Otóż kredyty te powinny być przeznaczone na:

- realizację inwestycji mających na celu poprawę struktury agrarnej, a także na

- sfinansowanie zakupu gruntów rolnych w celu:

a) utworzenia nowego gospodarstwa rolnego o powierzchni nie mniejszej od średniej powierzchni gruntów w gospodarstwach rolnych w danym województwie i nie większej niż 300 ha użytków rolnych,

17 Zob. $§ 10$ ust. 3 cyt. rozporządzenia Rady Ministrów z dnia 22 stycznia 2009 roku. 
b) powiększenia gospodarstwa mającego powierzchnię ogólną co najmniej 1 ha lub powierzchnię użytków rolnych nie mniejszą niż 1 ha przeliczeniowy, obliczoną według zasad stosowanych przy naliczaniu podatku rolnego, do powierzchni nie mniejszej od średniej powierzchni gruntów rolnych w gospodarstwach rolnych w danym województwie i nie większej niż 300 ha użytków rolnych.

Przy ustalaniu minimalnej powierzchni gospodarstwa rolnego uwzględnia się grunty stanowiące własność podmiotu wnioskującego o kredyt oraz dzierżawione przez niego w okresach wieloletnich. Przez dzierżawę w okresie wieloletnim rozumie się dzierżawę zawartą na okres dłuższy niż 3 lata i trwający co najmniej do końca okresu kredytowania.

O kredyt mogą się ubiegać:

- osoby fizyczne (rolnicy) o pełnej zdolności do czynności prawnych, z wyłączeniem emerytów i rencistów,

- osoby prawne,

- jednostki organizacyjne nieposiadające osobowości prawnej.

Kwota kredytu nie może przekraczać:

- $80 \%$ wartości nakładów inwestycyjnych na gospodarstwo rolne, nie więcej jednak niż 4 mln zł,

- wartości kupowanych gruntów rolnych, ustalonej na podstawie średnich cen rynkowych w danym województwie, wg Głównego Urzędu Statystycznego.

Różnica między wartością nakładów inwestycyjnych związanych z zakupem gruntów rolnych a kwotą udzielonego kredytu stanowi tzw. wkład własny kredytobiorcy. Jego oceny dokonuje bank na podstawie dokumentów przedłożonych przez inwestora przed podpisaniem umowy kredytowej. Forma, w jakiej zostanie wniesiony wkład własny oraz jego wartość, muszą zostać w sposób szczególny określone w planie przedsięwzięcia inwestycyjnego oraz w umowie kredytowej.

Kredyt może zostać udzielony maksymalnie na 15 lat, zaś karencja w jego spłacie nie może przekraczać dwóch lat.

Oprocentowanie kredytu jest zmienne i nie może wynosić więcej niż 1,6 stopy redyskontowej weksli przyjmowanych od banków do redyskonta przez Narodowy Bank Polski w stosunku rocznym. Dopłaty Agencji Restrukturyzacji i Modernizacji Rolnictwa do oprocentowania kredytów z linii kredytowej „Inwestycje podstawowe" wynoszą połowę oprocentowania kredytu, a do pozostałych kredytów (z wyłączeniem linii klęskowych) 0,75 oprocentowania kredytu, przy czym minimalne 
oprocentowanie kredytów inwestycyjnych płacone przez kredytobiorcę wynosi 2\% w skali roku.

Dla potrzeb sformułowania uogólniających wniosków co do skuteczności analizowanej tutaj formy wspierania poprawy struktury obszarowej gospodarstw rolnych pożytecznym będzie przywołane kilku danych statystycznych ${ }^{18}$. Otóż w 2010 roku kredyty objęte dopłatami Agencji Restrukturyzacji i Modernizacji Rolnictwa do ich oprocentowania oferowane były w ramach 13 linii kredytowych. Największe znaczenie $\mathrm{w}$ stymulowaniu poprawy struktury obszarowej miały w poniższej kolejności kredyty: na zakup użytków rolnych, na zakup użytków rolnych przeznaczonych na utworzenie lub powiększenie gospodarstwa rodzinnego w rozumieniu ustawy o kształtowaniu ustroju rolnego oraz na utworzenie lub urządzenie gospodarstwa rolnego przez osoby, które nie ukończyły 40 roku życia.

W 2010 roku banki udzieliły 12159 kredytów inwestycyjnych z dopłatami Agencji do ich oprocentowania na łączną kwotę 2379,63 mln. zł. Pozytywnym aspektem wspierania przez Agencję kredytowania rolnictwa jest odnotowana w tym roku zdecydowanie największa liczba kredytów na zakup gruntów rolnych. Udzieliły ich banki 5762 na łączną kwotę 802,51 mln zł (kredyty te stanowiły 48\% ogólnej liczby kredytów). W drugiej kolejności, w liczbie 3761, uplasowały się kredyty dla młodych rolników (udzielono ich na kwotę $882,82 \mathrm{mln}$ zł). Te ostatnie kredyty stanowią $31 \%$ ogółu kredytów. W trzeciej kolejności (10\%) plasują się kredyty na realizację inwestycji w gospodarstwach rolnych, w działach specjalnych produkcji rolnej i w przetwórstwie produktów rolnych.

W układzie wojewódzkim najwyższe, ogólne kwoty kredytów odnotowano w województwach: wielkopolskim, kujawsko-pomorskim, mazowieckim. W tym ostatnim odnotowano wprawdzie największą liczbę udzielonych kredytów (857), a dla porównania, w woj. kujawsko-pomorskim udzielono 783 kredyty, w wielkopolskim 751. Ogólna natomiast kwota udzielonych kredytów plasuje województwo mazowieckie dopiero na trzecim miejscu i wyniosła 73,5 mln zł. (w woj. wielkopolskim i kujawsko-pomorskim odpowiednio $139,1 \mathrm{mln}$ zł oraz 112,2 mln zł). Tak jak w poprzednich latach, najmniejszą liczbę kredytów odnotowano w województwach małopolskim, śląskim, świętokrzyskim oraz podkarpackim (odpowiednio 37 na kwotę 2,7 mln zł, 43 na kwotę $82 \mathrm{mln}$ zł, 136 na kwotę 9,9 mln zł).

W ramach preferencyjnych kredytów inwestycyjnych największe kwoty zostały w kolejności przeznaczone na:

- zakup gruntów rolnych (1076 mln zł, 73,2 tys. ha),

- zakup, budowę, modernizację, adaptację i remont budynków (506 mln zł),

Zaczerpnięto je ze sprawozdania z działalności Agencji Restrukturyzacji i Modernizacji Rolnictwa w 2010 roku. 
- zakup maszyn i urządzeń (247 mln zł, 25772 szt.),

- zakup ciągników 219 mln zł, 214 szt.).

Jeśli chodzi o aktywność rolników w pozyskiwaniu tych kredytów, to w układzie wojewódzkim przedstawia się podobnie jak w odniesieniu do preferencyjnych kredytów na zakup gruntów rolnych.

I jeszcze jeden wskaźnik wart jest przywołania. Otóż wśród kredytów preferencyjnych kredyty, których celem jest poprawa struktury agrarnej, zdecydowanie dominują. Liczba kredytobiorców wynosi 58,02\% ogółu kredytobiorców, a ich procentowy udział w ogólnej liczbie kredytobiorców wynosi 46,58\%. Ten stan rzeczy prowadzi zatem do generalnego wniosku, że ten kierunek kredytowania powinien być zdecydowanie kontynuowany. Zainteresowanie tym kredytem uznać należy jako przejaw samoistnych działań rolników w kierunku zwiększania rozmiarów produkcji, a co za tym idzie, także dochodów poprzez powiększenie obszaru gospodarstwa rolnego.

W pierwszych latach 90-tych ubiegłego stulecia podjęto także kolejną próbę poprawy struktury obszarowej gospodarstw rolnych, tym razem poprzez wykorzystanie przepisów ustawy z dnia 19 października 1991 roku o gospodarowaniu nieruchomościami rolnymi Skarbu Państwa oraz o zmianie niektórych ustaw ${ }^{19}$. Zadania powołanej na podstawie tej ustawy Agencji Własności Rolnej Skarby Państwa określone zostały stosunkowo szeroko. Wśród zadań wskazanych w art. 6 tej ustawy, zwrócić należy uwagę na te, o których mowa w pkt 5, 7, i 8 tego artykułu. Otóż do zadań tam wyszczególnionych zalicza się: tworzenie gospodarstw rolnych, a zwłaszcza powiększanie istniejących gospodarstw rodzinnych ${ }^{20}$, popieranie i organizowanie na gruntach rolnych Skarbu Państwa gospodarstw prywatnych, tworzenie miejsc pracy w związku z restrukturyzacją państwowej gospodarki rolnej. To ostatnie zadanie z katalogu określonych analizowaną tutaj ustawą zadań restrukturyzacyjnych Agencji Własności Rolnej Skarbu Państwa uznać należy za ważne społecznie, gdyż w wyniku likwidacji państwowych gospodarstw rolnych utraciło pracę prawie pół miliona osób, zaś w nowo powstałych, najczęściej dzierżawionych, dużych gospodarstwach rolnych, utworzonych na bazie likwidowanych gospodarstw, pracę znalazło niewiele ponad 100 tysięcy osób, a więc zaledwie co 5-ty pracownik byłego państwowego gospodarstwa rolnego.

Zauważyć w kolejności należy, że realizowany w pierwszych latach 90-tych liberalny kurs polityki gospodarczej Państwa sprawił, że zamiast umacniać istniejące już gospodarstwa rolne (także je tworzyć), stawiano na tworzenie gospodarstw wiel-

19 Dz.U. Nr 107, poz. 464 (tekst pierwotny).

20 Po zmianie dokonanej ustawą z dnia 11 kwietnia 2003 roku o kształtowaniu ustroju rolnego, Dz.U. Nr 64 poz. 592 ze $\mathrm{zm}$. 
koobszarowych, co w dłuższej perspektywie odbiło się niekorzystnie na strukturze produkcji rolnej w nowo tworzonych gospodarstwach w ten sposób, że często odchodzono od produkcji zwierzęcej i koncentrowano się na uprawie zbóż, co w efekcie prowadziło do monokultury upraw na zagospodarowywanych gruntach rolnych Skarbu Państwa.

Analizując dalej skuteczność i efektywność prowadzonych działań Państwa w zakresie poprawy struktury obszarowej gospodarstw rolnych w oparciu o mienie rolne Skarbu Państwa, warto zwrócić uwagę na stanowisko, jakie w tej sprawie zajął Sejm Rzeczypospolitej Polskiej. Otóż w ocenie Sejmu wytyczone przez ten organ zadanie wykorzystania ziemi popegeerowskiej na powiększenie indywidualnych gospodarstw rolnych nie zostało wykonane. Wiele natomiast firm, które wydzierżawiają ziemię popegeerowską, korzysta $\mathrm{z}$ wielomilionowych kwot dopłat bezpośrednich, sięgających niekiedy więcej niż $7 \mathrm{mln}$ zł rocznie. Ze stanowiskiem tym trudno się nie zgodzić. Nieprawidłowa dystrybucja dopłat bezpośrednich nie sprzyja raczej umacnianiu gospodarstw rodzinnych. Umacnia się nimi bardziej wielkoobszarowe gospodarstwa rolne, które udało się w większości utworzyć na początku transformacji ustrojowej, w pierwszych latach 90-tych ubiegłego stulecia. Wsparcie dopłatami bezpośrednimi pozostałych gospodarstw rolnych pozwala jedynie na utrzymanie ich dotychczasowego status quo ${ }^{21}$.

Dopłaty bezpośrednie, jako najszerzej stosowany we Wspólnej Polityce Rolnej instrument finansowego wspierania dochodów unijnego producenta rolnego, wywołują wiele kontrowersji. W Polsce przykładowo zwraca się coraz częściej uwagę na zbyt liberalne kryteria dostępu do tego świadczenia. Powoduje to, że dopłaty bezpośrednie przysługują zarówno gospodarstwom, które utrzymują uprawy w należytej kulturze rolnej, jak również gospodarstwom funkcjonującym na słabych glebach i ,pozorującym” tylko uprawę ziemi z myślą o otrzymaniu dopłat ${ }^{22}$. Ta grupa gospodarstw rolnych, z przyczyny wyżej podanej, nie jest zainteresowana ani sprzedażą, ani wydzierżawieniem posiadanej ziemi gospodarstwom rozwojowym. Ten stan rzeczy determinuje więc potrzebę skorygowania kryteriów dostępu do dopłat bezpośrednich. Sprawę ewentualnej korekty kryteriów dostępu polskich producentów rolnych do dopłat bezpośrednich należałoby załatwić w trybie pilnym, kiedy trwają jeszcze prace $w$ zakresie precyzowania kierunków oraz sposobu wykorzystywania środków finansowych w następnej perspektywie finansowej Unii Europejskiej, obejmującej lata 2014-2020.

21 O sposobie zagospodarowania mienia rolnego Skarbu Państwa w pierwszych latach 90-tych ubiegłego stulecia zob. W. Michna, op. cit., s. 23 i nast.; szczególną uwage zwraca przywoływana przez autora ekspertyzy publikacja „Rzeczypospolitej” z dnia 26 lipca 2007 roku, uwzględniająca krytyczna ocenę Sejmu Rzeczypospolitej Polskiej co do wykorzystania ziemi popegeerowskiej na powiększanie indywidualnych gospodarstw rolnych. 
Warto jeszcze zwrócić uwagę na przypadek prowadzący do wyhamowywania decyzji co do obniżania areału gospodarstwa rolnego poniżej jednego hektara użytków rolnych poprzez sprzedaż bądź wydzierżawienie części gruntów rolnych w niewielkich obszarowo gospodarstwach rolnych. Dotyczy to zwłaszcza gospodarstw z województw, w których dominują niewielkie obszarowo gospodarstwa rolne. Decyzje, o których tutaj mowa, nie są uzasadnione z następujących powodów. W przypadku obniżenia wielkości gospodarstwa poniżej jednego hektara użytków rolnych jego właściciel nie tylko utraci prawo do dopłat bezpośrednich, ale stanie się również podatnikiem podatku od nieruchomości, który jest zdecydowanie wyższy od podatku rolnego. Ponadto w przypadku sprzedaży całego gospodarstwa rolnego o areale poniżej 1 ha użytków rolnych czynność ta objęta będzie również wyższym podatkiem. W tym stanie rzeczy wielu rolników posiadających niewielkie obszarowo gospodarstwa rolne nie decyduje się dzisiaj na zmniejszenie ich powierzchni poniżej jednego hektara użytków rolnych, aby przez to nie stać się podatnikiem mniej korzystnego od strony finansowej podatku oraz nie utracić dostępu do dopłat bezpośrednich.

Od czasu uzyskania przez Polskę członkostwa Unii Europejskiej uruchomione zostały kolejne działania stymulujące poprawę struktury obszarowej gospodarstw rolnych. Przewidywały je następujące kolejno po sobie programy pomocowe wspólfinansowane z funduszy rolnych Unii Europejskiej (SAPARD, Plan Rozwoju Obszarów Wiejskich na lata 2004-2006, Sektorowy Program Operacyjny „Restrukturyzacja sektora żywnościowego oraz rozwój terenów wiejskich na lata 2004-2006" oraz realizowany w obecnej perspektywie finansowej Unii Europejskiej Program Rozwoju Obszarów Wiejskich na lata 2007-2013). Programy te nastawione w głównej mierze na stymulowanie pożądanych przekształceń strukturalnych w rolnictwie wyzwalają jednocześnie wśród rolników motywację do poprawy struktury obszarowej prowadzonych przez nich gospodarstw rolnych. Motywacje takie wyzwalane są nawet w przypadku tych działań, w których wśród kryteriów dostępu do przewidzianego w nich świadczenia nie ma wymogu zwiększenia areału gospodarstwa rolnego.

Wśród działań przewidzianych przywołanymi wyżej programami pomocowymi podstawowe natomiast znaczenie dla poprawy struktury obszarowej gospodarstw rolnych zdają się mieć renty strukturalne. Wśród kryteriów dostępu do tego świadczenia na pierwszy plan wybijają się wymogi obszarowe, jakie powinny zostać spełnione zarówno po stronie rolnika-beneficjenta renty strukturalnej, jak i jego następcy czy innego rolnika, który powiększa obszarowo prowadzone już przez siebie gospodarstwo rolne. Renty strukturalne mają spełniać inną jeszcze ważną funkcję, mianowicie przyspieszać wymianę pokoleniową w gospodarstwach rolnych. Ta 
ostatnia funkcja wynika z przeświadczenia, że młody rolnik daje lepszą gwarancję do dokonywania szerszych przekształceń strukturalnych w przejętym gospodarstwie rolnym poprzez różnego rodzaju przedsięwzięcia inwestycyjne, zmiany w strukturze produkcji, czy kolejne zakupy gruntów rolnych.

Na użytek rozważań zawartych w niniejszej pracy wypada pokrótce przeanalizować zagadnienie, jak w przepisach trzech już, kolejno następujących po sobie regulacjach prawnych dotyczących rent strukturalnych, zostały określone obszarowe kryteria dostępu do renty strukturalnej.

W pierwszej regulacji prawnej dotyczącej rent strukturalnych zawartej w przepisach ustawy z dnia 26 kwietnia 2001 roku o rentach strukturalnych w rolnictwie ${ }^{23}$ prawo do renty strukturalnej, zgodnie z art. 3, ust. 1 pkt 5 tej ustawy, przysługiwało rolnikowi, jeżeli ten, m.in. przekazał gospodarstwo rolne w całości o łącznej powierzchni wynoszącej co najmniej 3 ha, przy czym warunek ten uważało się za spełniony, jeżeli grunty wchodzące w skład tego gospodarstwa przekazane zostały na powiększenie jednego lub kilku gospodarstw już istniejących, a ich powierzchnia nie mogła być mniejsza niż 15 ha użytków rolnych. Ustawodawca upoważnił w tym ostatnim przypadku Radę Ministrów do wskazania w drodze rozporządzenia województw lub powiatów, w których powierzchnia powiększonego gospodarstwa mogła być mniejsza od 15 ha, określając przy tym wymaganą w danym województwie lub powiecie powierzchnię powiększonego gospodarstwa, przy uwzględnieniu średniej powierzchni gospodarstwa w województwie lub w powiecie ${ }^{24}$. Tak rygorystycznie określone kryteria obszarowe z góry ograniczały dostęp wielu rolników do renty strukturalnej, zwłaszcza w województwach, w których średnia powierzchnia gospodarstwa rolnego wynosiła poniżej 3 ha. Niewielka liczba przyznanych w trybie przepisów tej ustawy rent strukturalnych nie odegrała w praktyce większej roli w poprawie struktury obszarowej gospodarstw rolnych.

Pod rządami kolejnej regulacji prawnej dotyczącej rent strukturalnych obszarowe kryteria dostępu do renty strukturalnej uległy istotnemu złagodzeniu. Tak więc zgodnie z przepisem $\S 4$ pkt 4 rozporządzenia Rady Ministrów z dnia 30 kwietnia 2004 roku w sprawie szczegółowych warunków i trybu udzielania pomocy finansowej na uzyskanie rent strukturalnych objętej planem rozwoju obszarów wiejskich ${ }^{25}$ rentę strukturalną przyznaje się producentowi rolnemu, który m.in. przekazał w całości gospodarstwo rolne o łącznej powierzchni użytków rolnych wynoszących co najmniej 1 ha. Przepisy tego rozporządzenia nie zawierały dodatkowych wymo-

Dz.U. Nr 52, poz. 539 ze zm.

Podstawa prawna: art. 6 , ust. analizowanej ustawy; delegacja ustawowa w tym przypadku nie została wykonana.

Dz.U. Nr 114, poz. 1191 ze zm.; rozporządzenie powyższe wydane zostało na podstawie art. 3 ust 2. pkt 1 ustawy z dnia 28 listopada 2003 roku o wspieraniu rozwoju obszarów wiejskich ze środków pochodzących z Sekcji Gwarancji Europejskiego Funduszu Orientacji i Gwarancji Rolnej (Dz.U. Nr 229, poz. 2273 oraz Dz.U. z 2004 r. $\mathrm{Nr} 42$, poz 386. 
gów obszarowych, jakie powinny być dopełnione zarówno przez przekazującego, jak i przez przejmującego gospodarstwo rolne. Nie ulega chyba wątpliwości, że tak z kolei łagodnie określone obszarowe kryteria dostępu do renty strukturalnej nie mogły stanowić istotnego instrumentu stymulującego poprawę struktury obszarowej gospodarstw rolnych.

Obecnie obowiązujące przepisy dotyczące rent strukturalnych powróciły do ostro określonych obszarowych kryteriów dostępu do tego świadczenia. Rozporządzenie Ministra Rolnictwa i Rozwoju Wsi z dnia 19 czerwca 2007 roku w sprawie szczegółowych warunków i trybu przyznawania pomocy finansowej w ramach działania „Renty strukturalne” objętego Programem Rozwoju Obszarów Wiejskich na lata $2007-2013^{26}$ było aż 6-krotnie nowelizowane, zaostrzając każdorazowo kryteria dostępu do renty strukturalnej. Zgodnie $\mathrm{z}$ aktualnym stanem prawnym ${ }^{27}$ renta strukturalna przysługuje rolnikowi, który m.in. przekazał całe gospodarstwo rolne o łącznej powierzchni użytków rolnych wynoszącej co najmniej 6 ha, a w przypadku gospodarstw rolnych położonych w woj. małopolskim, śląskim lub świętokrzyskim - co najmniej 3 ha. Zgodnie z $§ 6$ analizowanego rozporządzenia warunek przekazania gospodarstwa rolnego uważa się za spełniony, jeżeli:

- w przypadku następcy powierzchnia użytków rolnych wchodzących po ich przejęciu w skład jego gospodarstwa nie może być mniejsza niż średnia powierzchnia gruntów rolnych w kraju ${ }^{28}$; gdyby jednak ta powierzchnia była mniejsza od średniej krajowej, to następca powinien ją uzupełnić w trybie przepisów § 5 rozporządzenia Ministra Rolnictwa i Rozwoju Wsi z dnia 17 października 2007 roku w sprawie szczegółowych warunków i trybu przyznawania pomocy finansowej w ramach działania „Ułatwianie startu młodym rolnikom", objętego Programem Rozwoju Obszarów Wiejskich na lata $2007-2013,{ }^{29}$

- w przypadku gospodarstwa innego rolnika, na rzecz którego nastąpiło przeniesienie własności gospodarstwa rolnego należącego do wnioskującego o rentę strukturalną, z myślą o jego powiększeniu, powierzchnia nie może być mniejsza niż średnia powierzchnia gruntów rolnych w gospodarstwie rolnym w kraju, z tym że w przypadku przekazania gospodarstwa rolnego o powierzchni użytków rolnych większej niż 10 ha, powierzchnia powiększanego gospodarstwa po powiększeniu powinna być większa co najmniej

Dz.U. Nr 109, poz. 750 ze zm.; rozporządzenie powyższe zostało wydane na podstawie art. 29 ust 1 pkt 4 ustawy z dnia 7 marca 2007 roku o wspieraniu rozwoju obszarów wiejskich z udziałem środków Europejskiego Funduszu Rolnego na Rzecz Rozwoju Obszarów Wiejskich (Dz.U. Nr 64, poz. 427 ze zm.). Ukształtowanym ostatecznie rozporządzeniem zmieniającym z dnia 16 lipca 2010 roku (Dz.U. Nr 131, poz. 886). 
o $10 \%$ od powierzchni użytków rolnych wchodzących w skład przekazywanego gospodarstwa rolnego.

Na użytek prowadzonej tutaj analizy warto przywołać kilka jeszcze warunków, od spełnienia których uzależnione jest uzyskanie renty strukturalnej, a ustanowionych z myślą o stymulowaniu przekształceń strukturalnych w gospodarstwach rolnych.

Zwrócić tutaj należy m.in. uwagę na wymóg przekazania wszystkich użytków rolnych, będących zarówno przedmiotem odrębnej własności rolnika oraz jego współmałżonka, jak również przedmiotem ich współwłasności (§ 6 ust 1, pkt 1 rozporządzenia). Przy ustalaniu powierzchni użytków rolnych gospodarstwa rolnego po powiększeniu sumuje się powierzchnię użytków rolnych stanowiących przedmiot zarówno własności, także użytkowania wieczystego oraz dzierżawy, jeżeli umowa dzierżawy została zawarta na piśmie na okres co najmniej pięciu lat ( 6 ust. 5 rozporządzenia).

W zamyśle prawodawcy do przekształceń strukturalnych w gospodarstwach rolnych prowadzą inne jeszcze wymogi, które powinien spełnić rolnik, z którym może być zawarta umowa o przekazaniu gospodarstwa, a mianowicie:

- posiadać odpowiedni wiek (następca poniżej 40 lat, zaś rolnik powiększający gospodarstwo poniżej 50 lat),

- zobowiązać się do prowadzenia osobiście działalności rolniczej na przejętych użytkach rolnych przez okres co najmniej 5 lat,

- zobowiązać się do warunku dotyczącego minimalnej powierzchni użytków rolnych wchodzących w skład gospodarstwa rolnego następcy ${ }^{30}$,

- posiadać odpowiednie kwalifikacje rolnicze ${ }^{31}$,

- zobowiązać się do przedłożenia w biurze powiatowym Agencji Restrukturyzacji i Modernizacji Rolnictwa potwierdzonej za zgodność z oryginałem przez pracownika tej Agencji kopii planu rozwoju przejmowanego gospodarstwa, o którym mowa w cytowanym wyżej rozporządzeniu Ministra Rolnictwa i Rozwoju Wsi z dnia 17 października 2007 roku (wymóg ten dotyczy tylko następcy).

Ten ostatni wymóg, na co należy zwrócić szczególną uwagę, został w aktualnym stanie prawnym zdecydowanie zmodyfikowany w ten sposób, że plan rozwoju przejmowanego gospodarstwa rolnego tworzony jest jednocześnie na użytek wnio- 
sku następcy o pomoc w ramach działania „Ułatwianie startu młodym rolnikom”. Tak określony wymóg ma przeciwdziałać fikcji dotychczasowych planów modernizacji przejmowanych gospodarstw rolnych, sporządzanych w trybie dotychczasowych przepisów o rentach strukturalnych. Przyjęte obecnie rozwiązanie stwarza dla Agencji Restrukturyzacji i Modernizacji Rolnictwa możliwość zastosowania działania regresowego w postaci cofnięcia następcy świadczenia przyznanego mu w ramach działania „Ułatwianie startu młodym rolnikom”.

Dokonując próby oceny przyjętych rozwiązań w poszczególnych, przywołanych wyżej regulacjach prawnych dotyczących rent strukturalnych, stwierdzić należy, że skuteczność tego działania została jednoznacznie osłabiona pod rządami drugiej regulacji prawnej, tj. w latach 2004-2006. Liberalnie określone wówczas obszarowe kryteria dostępu do renty strukturalnej sprawiły, że przekazywanie gospodarstw prowadziło jedynie do przyspieszania wymiany pokoleniowej, nie powodując przy tym poprawy struktury obszarowej przejmowanych gospodarstw rolnych. Dodać tutaj należy, że niejednokrotnie bywało również tak, że gospodarstwo rolne przekazywane było dziecku zatrudnionemu poza rolnictwem, a rolnik-beneficjent renty strukturalnej nadal faktycznie prowadził to gospodarstwo, podczas gdy jego następca w dalszym ciągu pracował poza rolnictwem, a co najwyżej pomagał dorywczo rodzicom w prowadzeniu jego gospodarstwa.

Renty strukturalne pod rządami wszystkich regulacji prawnych spełniały niewątpliwie funkcję socjalną w odniesieniu do starszych rolników. Przy równoległym zasilaniu przejętych gospodarstw rolnych dopłatami bezpośrednimi pozwalały na podtrzymanie ich egzystencji, nie prowadząc przy tym do pożądanych zmian w ich strukturze obszarowej.

Renty strukturalne w Polsce wzorowane są na wcześniejszych emeryturach wdrażanych już dużo wcześniej w wielu krajach byłej ,piętnastki” Unii Europejskiej. W najszerszym zakresie polski prawodawca wzorował się tutaj na rozwiązaniach francuskich. Zgodnie $\mathrm{z}$ tamtejszymi rozwiązaniami jednym $\mathrm{z}$ warunków jest przekazanie (poprzez sprzedaż lub wydzierżawienie) gospodarstwa innemu rolnikowi (może to być np. istniejące już gospodarstwo syna lub córki). Czynność ta powinna w każdym przypadku prowadzić do powiększenia obszaru gospodarstwa przejmującego. We Francji, uruchamiając ten, a także szereg innych jeszcze instrumentów oddziaływujących na poprawę struktury obszarowej gospodarstw rolnych, poprawiła się w sposób istotny struktura tych gospodarstw, głównie kosztem redukcji gospodarstw niewielkich obszarowo.

W fachowej literaturze prawniczej, a jeszcze bardziej w ekonomicznej, wcześniejsze emerytury w krajach byłej ,piętnastki” oceniane są różnie. Każdy z tych krajów, uwzględniając swoją specyfikę rolnictwa, przyjmował różne rozwiązania w tym zakresie, wdrażając przy tym nie zawsze te same, towarzyszące temu działaniu in- 
strumenty wspierania poprawy struktury obszarowej gospodarstw rolnych. Generalnie podkreśla się, że największe znaczenie przypisać wprawdzie należy wcześniejszym emeryturom, choć ich najbardziej aktywna funkcja to przyspieszanie wymiany pokoleniowej w gospodarstwach rolnych.

Uwzględniając sytuację demograficzną krajów byłej „piętnastki”, obserwujemy aktualnie zmianę poglądów co do funkcji rent strukturalnych. Rozważa się również zasadność kontynuacji wcześniejszych emerytur w przyszłych programach pomocowych, które we wcześniejszych latach miały też przeciwdziałać bezrobociu młodych osób na terenach wiejskich. Zwraca się przy tym uwagę na to, że proces modernizacji sektora rolnego trwa w tych krajach nieprzerwanie od wielu już lat i w przeciwieństwie do krajów nowo przyjętych do Unii Europejskiej proces koncentracji gruntów odbywał się na zasadach rynkowych, w sytuacji intensywnego wzrostu gospodarczego, który był oparty w głównej mierze na zwiększaniu zatrudnienia w przemyśle. W tych okolicznościach systemy ubezpieczeń społecznych rolników działały głównie na rzecz wymiany pokoleniowej w rolnictwie oraz wspomagająco na rzecz wsparcia pożądanego obrotu ziemią̧

Poszczególne okresy wdrażania rent strukturalnych w Polsce można podsumować następująco. Renty strukturalne przyznane przed uzyskaniem przez nasz kraj członkostwa w Unii Europejskiej, zważywszy na ich małą liczbę, nie odegrały większej roli, jeśli chodzi o wyznaczone im funkcje. Pod rządami drugiej z przywołanych wyżej regulacji prawnych dotyczących rent strukturalnych obejmujących lata 2004-2006 rolnicy złożyli ogółem 56326 wniosków o renty strukturalne. Z tej liczby renty strukturalne przyznano 53594 rolnikom. Złożone wnioski stanowią 3,16\% ogółu gospodarstw rolnych w Polsce. Liczba przekazanych gospodarstw wyniosła $53594^{33}$. Ta liczba przekazanych gospodarstw rolnych świadczy o dużym zainteresowaniu rolników tym świadczeniem. Bezsprzecznie w gospodarstwach tych doszło do wymiany pokoleniowej. Zważywszy natomiast na to, że renty strukturalne pod rządami obowiązujących wówczas przepisów nie były ukierunkowane na przekształcanie gospodarstw nierozwojowych w rozwojowe, zatem można przyjąć, że efekt strukturalnej interwencji Państwa podejmowanej w tym zakresie nie był znaczący dla poprawy konkurencyjności naszego rolnictwa. Kluczowe bowiem znaczenie w polskim rolnictwie ma zwiększenie powierzchni użytków rolnych w gospodarstwach rozwojowych bądź w tych, które stan taki mogą osiągnąć. Nie sprzyjały

Szerzej na ten temat zob. Instrumenty oddziaływania Państwa na kształtowanie struktury obszarowej gospodarstw rolnych w Polsce; rola systemu ubezpieczenia społecznego rolników w kształtowaniu tej struktury. Stan obecny i rekomendacje na przyszłość oraz propozycje nowych rozwiązań dotyczących tego obszaru dla systemu ubezpieczeń społecznych rolników, ekspertyza wykonana w IERiGŻ PIB pod kierunkiem A. Sikorskiej dla Ministerstwa Rolnictwa i Rozwoju Wsi, Warszawa 2009; w szczególności zob. zawarte w niej rozważania na temat roli systemów emerytalno-rentowych w stymulowaniu przemian strukturalnych w rolnictwie, s. 104 i nast. Źródło: System Informacji Zarządczej Agencji Restrukturyzacji i Modernizacji Rolnictwa. 
Instrumenty kształtowania struktury obszarowej gospodarstw rolnych w Polsce...

temu obowiązujące wówczas w tym zakresie przepisy prawne, a zwłaszcza liberalnie określone obszarowe kryteria dostępu do renty strukturalnej.

W obecnej perspektywie finansowej nastąpiła słusznie radykalna zmiana kryteriów dostępu do renty strukturalnej, zwłaszcza w odniesieniu do kryterium obszarowego. Mimo to zainteresowanie rolników rentami strukturalnymi nie zmniejszyło się. Działanie „Renty strukturalne” uruchomiono w czerwcu 2007 roku, przeprowadzając od tamtego czasu zaledwie trzy nabory wniosków na ogólną ich liczbę $28528^{34}$.Według danych na dzień 31 grudnia 2010 roku wydano 13678 decyzji przyznających renty strukturalne dla wniosków złożonych w 2007 i w 2008 roku. W 2010 roku tytułem przyznanych już rent strukturalnych wypłacono beneficjentom 1319,2 mln zł, z czego 1128,6 mln zł dla 51753 beneficjentów z tytułu zobowiązań za okres 2004-2006, a 190,6 mln zł dla 13514 beneficjentów z tytułu zobowiązań za lata 2007-2013. Zauważyć w tym miejscu należy, że renta strukturalna jest świadczeniem finansowym o charakterze ciągłym, a jego beneficjenci otrzymują je comiesięcznie, aż do osiągnięcia wieku emerytalnego, często przez okres 10 lat. Jak widać z powyższych danych statystycznych, kwota zobowiązań z tytułu przyznanych rent strukturalnych jest znacząca, zwłaszcza z tytułu zobowiązań powstałych w latach 2004-2006. Jeśli skojarzymy ją z niewiele znaczącymi efektami w zakresie poprawy struktury obszarowej gospodarstw rolnych, to pod znakiem zapytania pozostaje racjonalność podejmowanych w tamtym okresie działań.

Jakie natomiast efekty w zakresie poprawy struktury obszarowej gospodarstw rolnych przyniosą renty strukturalne przyznane po 2007 roku, o tym dzisiaj trudno jednoznacznie przesądzać. Pełna ocena będzie możliwa dopiero po rozliczeniu tego, jak również innych jeszcze działań wspierających przemiany strukturalne w rolnictwie w obecnej perspektywie finansowej. Niemniej jednak już dzisiaj można twierdzić, że również ten okres nie przyniesie znaczących zmian w zakresie poprawy struktury obszarowej gospodarstw rolnych, jeśli zważyć na małą liczbę przyznanych rent strukturalnych oraz wyczerpanie się środków finansowych na to świadczenie.

Skoro mowa o innych działaniach mających bezpośredni bądź pośredni wpływ na przekształcenia strukturalne w gospodarstwach rolnych, to na użytek rozważań zawartych w niniejszej pracy warto na nie wskazać, określić ich cele oraz skutki. Bez wątpienia istotne znaczenie w tym zakresie przypisać należy „Modernizacji gospodarstw rolnych"- działaniu Programu Rozwoju Obszarów Wiejskich na lata 2007-2013. Wypada wyrazić w tym miejscu pogląd, aby w strategii ferowania pomocy finansowej $\mathrm{w}$ ramach tego działania nie umknęły z pola widzenia gospodarstwa z grupy gospodarstw niskotowarowych, które miałyby szansę przekształcić się

Źródło: Sprawozdanie z działalności Agencji Restrukturyzacji i Modernizacji Rolnictwa za 2010 rok, www. arimr,gov.pl. Zawarte w dalszych wywodach informacje statystyczne zaczerpnięto również z powyższego źródła. 
w gospodarstwa rozwojowe. Na marginesie należy w tym miejscu także zauważyć, że zobowiązanie Agencji Restrukturyzacji i Modernizacji Rolnictwa z tytułu wdrożenia tego działania ma charakter świadczenia jednorazowego, w postaci refundacji połowy kosztów kwalifikowanych objętego pomocą przedsięwzięcia inwestycyjnego. W zestawieniu z kwotą zobowiązania powstałego w związku z przyznaniem renty strukturalnej zobowiązanie $\mathrm{z}$ tytułu objęcia wsparciem finansowym modernizacji gospodarstwa rolnego będzie z reguły zdecydowanie niższe, a efekt strukturalny, zważywszy na ostre kryteria dostępu do tej pomocy, pewny i niejednokrotnie daleko większy aniżeli w przypadku rent strukturalnych.

Do listy ważnych działań Programu Rozwoju Obszarów Wiejskich na lata 20072013 wypada zaliczyć następnie działanie „Wspieranie gospodarowania na obszarach górskich i innych obszarach o niekorzystnych warunkach gospodarowania". Działanie to należy uznać za ważne, gdyż brak wsparcia rolnictwa na tych terenach może powodować zjawisko narastania odłogów oraz ich wyludnianie. Zwłaszcza pierwsze $\mathrm{z}$ tych zjawisk nie jest pożądane $\mathrm{z}$ uwagi na narastające potrzeby $\mathrm{w}$ zakresie wyżywienia oraz pozyskiwania surowców pochodzenia rolniczego do produkcji odnawialnych źródeł energii.

Zwrócić należy też uwagę na działanie „Zalesianie gruntów rolnych”. Jego pozytywna rola wydaje się wynikać z tego, że ma ono prowadzić nie tylko do poprawy stanu środowiska naturalnego, ale przy racjonalnym jego wdrażaniu prowadzić do zrównoważonego współegzystowania gospodarek rolnej i leśnej.

Na zakończenie syntetycznego przeglądu działań, ważnych dla przekształceń strukturalnych w rolnictwie, pozostaje wskazać na działanie „Grupy producentów rolnych”. Rola tych grup nie jest jeszcze w Polsce należycie doceniana. Wynika to nie tylko z postaw samych rolników, którzy raczej niechętnie organizują się do grupowego współdziałania, ale również polityków i ekspertów rolnych. Istniejące już w Polsce grupy producentów rolnych tworzone są głównie z myślą o współdziałaniu w sferze przygotowania towarów do sprzedaży. Natomiast na drugi plan schodzi współdziałanie członków grupy producenckiej w zakresie prowadzenia produkcji rolnej. Istnieje zatem potrzeba sięgnięcia w tym zakresie do pozytywnych wzorców funkcjonowania tych organizacji w innych krajach Unii Europejskiej, a następnie podjęcia próby wdrożenia ich na polskim gruncie.

Na przekształcenia strukturalne w polskich gospodarstwach rolnych mają też wpływ wszystkie inne działania prowadzące do dostosowania naszych gospodarstw rolnych do standardów gospodarstw unijnych . Dotyczy to wszystkich gospodarstw rolnych, w tym może najbardziej tych, których celem jest osiągnięcie poziomu gospodarstwa rozwojowego. 
Instrumenty kształtowania struktury obszarowej gospodarstw rolnych w Polsce...

*****

Na zakończenie rozważań podjętych w niniejszej pracy pozostaje jeszcze sformułować kilka uogólniających wniosków, jakie nasuwają się na tle przeprowadzonej analizy.

1. Polska polityka rolna całego okresu powojennego słusznie utrzymywała pogląd, że niezadowalająca struktura obszarowa polskich gospodarstw rolnych wymaga podejmowania permanentnych działań na rzecz poprawy tej struktury. Działania takie, z różnym zresztą skutkiem, były i nadal są podejmowane, przy czym ich różnorodność zwiększyła się po 1990, a jeszcze bardziej po 2004 roku.

2. Działaniem, które miało w istotny sposób przyspieszyć poprawę struktury obszarowej gospodarstw rolnych, miały być renty strukturalne. $\mathrm{Z}$ analizy przeprowadzonej w niniejszej pracy wynika, że taki skutek renty strukturalne mogą powodować jedynie wtedy, gdy wśród kryteriów dostępu do tego świadczenia ustanowiony zostanie ostry sformułowany warunek poprawy struktury gospodarstwa rolnego po jego przejęciu od beneficjenta renty strukturalnej. Zasadność tego poglądu będzie mogła być potwierdzona jednoznacznie dopiero po zakończeniu wdrażania rent strukturalnych przewidzianych obecnym Programem Rozwoju Obszarów Wiejskich na lata 2007-2013, który takie właśnie kryteria ustanowił. Zastrzec jednak w tym miejscu należy, że ocena w tym zakresie może budzić wątpliwości z uwagi na małą liczbę rent strukturalnych przyznanych po 2007 roku.

3. W przyszłości większej aktywizacji oraz nakładów finansowych wymagać będą te działania w obecnym Programie Rozwoju Obszarów Wiejskich na lata 2007-2013, które sprawdziły się jako instrument prowadzący do stałych strukturalnych zmian w strukturze obszarowej polskich gospodarstw rolnych. Dlatego w następnym programie pomocowym realizacja powyższego wniosku powinna nastąpić nawet kosztem likwidacji niektórych mało efektywnych działań obecnego Programu oraz innej alokacji środków finansowych na przyjęte w nim działania.

4. Zasadnym wydaje się rozważenie nowego działania w kolejnym programie pomocowym dla rolnictwa i terenów wiejskich. Chodzi o działanie, którego celem byłoby wspieranie w gospodarstwach rolnych upraw surowców do produkcji odnawialnych źródeł energii oraz tzw. „,dobrej żywności”. Z działaniem tym powinna być związania możliwość przetwarzania tych surowców już w gospodarstwach rolnych. Miałoby to duży wpływ na poprawę sytuacji ekonomicznej, także gospodarstw słabszych, co w efekcie doprowadziłoby do ich przekształcenia w gospodarstwa rozwojowe.

5. Przeprowadzona w pracy analiza prowadzi również do krytycznego wniosku co do zakresu stosowania dopłat bezpośrednich, najszerzej stosowanego w Unii Europejskiej instrumentu Wspólnej Polityki Rolnej, absorbującego przy tym ok. 30\% 
środków budżetu unijnego. W Polsce praktyka wdrażania dopłat bezpośrednich wykazała istnienie wielu przypadków pozornego uprawiania ziemi, tylko po to, aby otrzymać te dopłaty. Taki stan rzeczy hamuje m.in. przepływ ziemi z nierozwojowych do już funkcjonujących gospodarstw rozwojowych bądź mogących funkcjonować jako rozwojowe. W tej sytuacji zasadnym wydaje się rozważenie potrzeby ustanowienia ostrzejszych wymogów uprawy ziemi, jako warunku do otrzymania dopłat bezpośrednich. Również jako zasadne byłoby można uznać rozważenie możliwości objęcia dopłatami bezpośrednimi jedynie osób prawnych i fizycznych użytkujących grunty rolne do 300 ha. W ten sposób zaoszczędzono by pokaźną ilość środków finansowych, które następnie można byłoby przeznaczyć na cele tworzenia rodzinnych gospodarstw rozwojowych. Chodzi tu zwłaszcza o te gospodarstwa, które już poprzez zwiększenie obszaru użytków rolnych mogłyby stać się gospodarstwami rozwojowymi, zdolnymi do odtwarzania potencjału produkcyjnego.

6. Już na sam koniec wniosek generalny. Poprawa struktur gospodarowania w rolnictwie nie zależy od różnorodności działań przewidzianych programami pomocowymi. Blisko 7-letni okres korzystania z unijnych środków finansowych, kierowanych na finansowanie Wspólnej Polityki Rolnej i taki sam okres pozostawania naszego kraju w strukturach Unii Europejskiej, zwłaszcza w obszarze wspólnotowego rynku artykułów żywnościowych, pozwala już na pełniejszą ocenę skuteczności wdrażanych instrumentów pomocowych. Generalnie przyjąć można, że instrumenty te pełnią jedynie funkcję wspomagającą, a w pewnym zakresie także ukierunkowywującą pożądane przekształcenia strukturalne w rolnictwie. Istotny natomiast wpływ na te przekształcenia ma przede wszystkim korzystny dla producenta rolnego rynek artykułów żywnościowych, który jest najlepszym determinantem rozwoju. Wszystkie zatem te względy należy mieć na uwadze, programując właściwe działania pomocowe, wśród których należałoby koncentrować się na tych, które przyniosły już w praktyce pożądane rezultaty $\mathrm{w}$ zakresie przekształceń strukturalnych w polskim rolnictwie. 


\section{Instruments for shaping the area structure of Polish agricultural holdings with particural emphasis on the role of financial instruments}

Key words: rural areas, spatial structure of farms, structural pensions

Commonly it is deemed, which is also confirmed in professional economical literature, that spatial structure of farms in Poland is insufficient and requires improvement. The need of this improvement is dictated by the necessity of increasing the amount of developing farms, which guarantee the fulfilment of always increasing internal and external demand on polish food and raw materials of agricultural origin necessary to produce renewable sources of energy. Actions of the state heading for improving the spatial structure of farms were taken in Poland, with different effect, throughout the whole post-war period but their intensification took place after 1990. The most important activities initiated after this year are: the supporting of crediting the purchasing of land through granting premiums to interest of bank loans and then applying different forms of financial support for structural transformations in agriculture, provided by actions of assistance programmes for agriculture and rural areas after 2004. Special role in this matter has been envisaged on structural pensions in agriculture. In practice it turned out however that non of these actions both taken separately and together have not caused significant positive changes in the spatial structure of farms. Therefore the general conclusion on the background of this analysis leads to the opinion that the essential influence on desired structural changes in agriculture, in it also on the improvement of spatial structure of farms, have mainly friendly to the producer market of foodstuff and that actions which were analysed in this paper one can impute only auxiliary function in these transformations. 